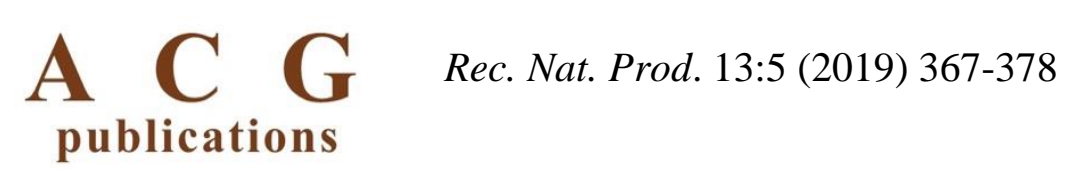

records of natural

products

\title{
Biodiversity and Secondary Metabolites of Marine Sponges from Turkey
}

\author{
Hajar Heydari $\odot^{1}$, Bülent Gözcelioğlu $\odot^{2}$ and Belma Konuklugil $\odot^{1^{*}}$

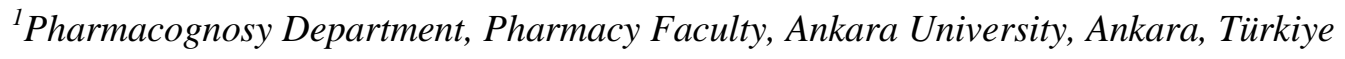 \\ ${ }^{2}$ Science and Society Department, Scientific and Technological Research Council of Türkiye \\ (TÜBITAK), Ankara, Türkiye
}

(Received July 31, 2018; Revised December 31, 2018; Accepted January 02, 2019)

\begin{abstract}
Turkey is surrounded by the Black Sea, the Aegean Sea and the Mediterranean sea, comprising a rich source of marine biodiversity. Among all marine species, sponges with a wide range of secondary metabolites are an important potential for drug discovery. There are many studies on sponges and their secondary metabolites, but not enough study about Turkish sponges. The present review gives an overview of the current research trends on secondary metabolites from Turkish marine sponges and some of their biological activities. Until today alkaloids, steroids and phenolic compounds have been isolated and determined from Turkish sponges. To our knowledge, this is the first review about Turkish sponges. Furthermore, we have tried to introduce our Marine Herbarium of Ankara University Pharmacy Faculty (MAP).
\end{abstract}

Keywords: Bioactivity; biodiversity; secondary metabolite; sponge (c) 2019 ACG Publications. All rights reserved.

\section{Introduction}

Marine natural products research has increased conspicuously during the recent decades. Marine species are rich sources of biodiversity with production of structurally diverse, novel and biologically active marine secondary metabolites. Among all the investigated marine species, marine sponges (Porifera) are accepted as the richest sources of new marine natural products. About $33 \%$ of all marine natural products have been isolated from sponges, which make them currently the most important source of unique secondary metabolites [1]. More than 5300 different compounds have been isolated from sponges and their associated microorganisms, and more than 200 new secondary metabolites are reported every year [2]. The compounds isolated from sponges have diverse structures including acids, alkaloids, esters, fatty acids, glycosides, ketones, lipids, macrolides, alcohols, peptides, peroxides, quinones, polyketides, steroids, terpenes, terpenoids, sterols with a vast range of biological activities such as antioxidant, antiviral, antibacterial, antifungal, antitumor, anticancer and antifouling activities [3-11]. Because of these properties, sponges are interesting candidates for the design of new drugs for the pharmaceutical industry [12]. Concerning the geographical location, Turkey is encompassed by Black Sea at the north, the Aegean Sea at the west, and the Mediterranean Sea at the south, therefore it is a peninsula which possesses about $8400 \mathrm{~km}$ of coastline. Despite this feature, there

\footnotetext{
*Corresponding author: E-Mail: belma.konuklugil@gmail.com; Phone+90312 2033092 Fax:+90312 2131081
} 
has been limited work on its marine secondary metabolites and their bioactivities. The record of marine sponges in the seas around the Turkey contains 141 species including 82 species from the Aegean Sea, 63 species from the Sea of Marmara, 51 species from the Levantine Sea, and 18 species from the Black Sea were [13-15]. It is worth notice that seven of these sponges were recorded in the previous works of our research group which are already included in sponge fauna of Turkey. These are Haliclona sarai (Pulitzer-Finali, 1969); Scalarispongia scalaris (Schmidt, 1862); Hyrtios collectrix (Schulze, 1880); Dendrectilla tremitensis (Pulitzer-Finali, 1983); Dictyonella incisa (Schmidt, 1880); Axinyssa aurantiaca (Schmidt, 1864); and Halichondria (Halichondria) contorta (Sarà, 1961). Moreover, a new Hymedesmia species, Hymedesmia (Hymedesmia) anatoliensis sp. nov. was also recorded by our group in west of Turkey. In 1885 the sponges from the coasts of Turkey were reported for the first time. The report contained 5 sponge species from the Strait of Çanakkale. The last report of Turkish marine sponges was released in 2016 which included 5 sponge species from the black Sea.

This review aims to summarize the biodiversity of the marine sponges of Turkey. Considering that more than 200 sponge species have been reported in Greek Aegean Sea, it is expected that the number of known sponge species of Turkey increases substantially with further fieldwork.

\section{Results and Discussion}

\subsection{Marine Herbarium of Ankara University Pharmacy Faculty}

Sponge samples were collected by scuba diving with a maximum diving depth of 40 meters. All samples were fixed in $70 \%$ ethyl alcohol. Sponge species were identified at the Zoological Museum of Amsterdam, the Netherlands. During our research on marine species, an herbarium of the collected samples was made and all the species were identified by Dr. Gözcelioğlu and Dr. Soest. This herbarium is located in Ankara University, Faculty of Pharmacy, Department of Pharmacognosy (MAP). The list of sponges and collected locations are shown in Table 1 and Figure 1. The most common species in Turkey as shown in Table 1, is Agelas oroides. Furthermore, in this herbarium there are other marine species like tunicate, coral, anemone, etc. that were not included in this study.

Black Sea

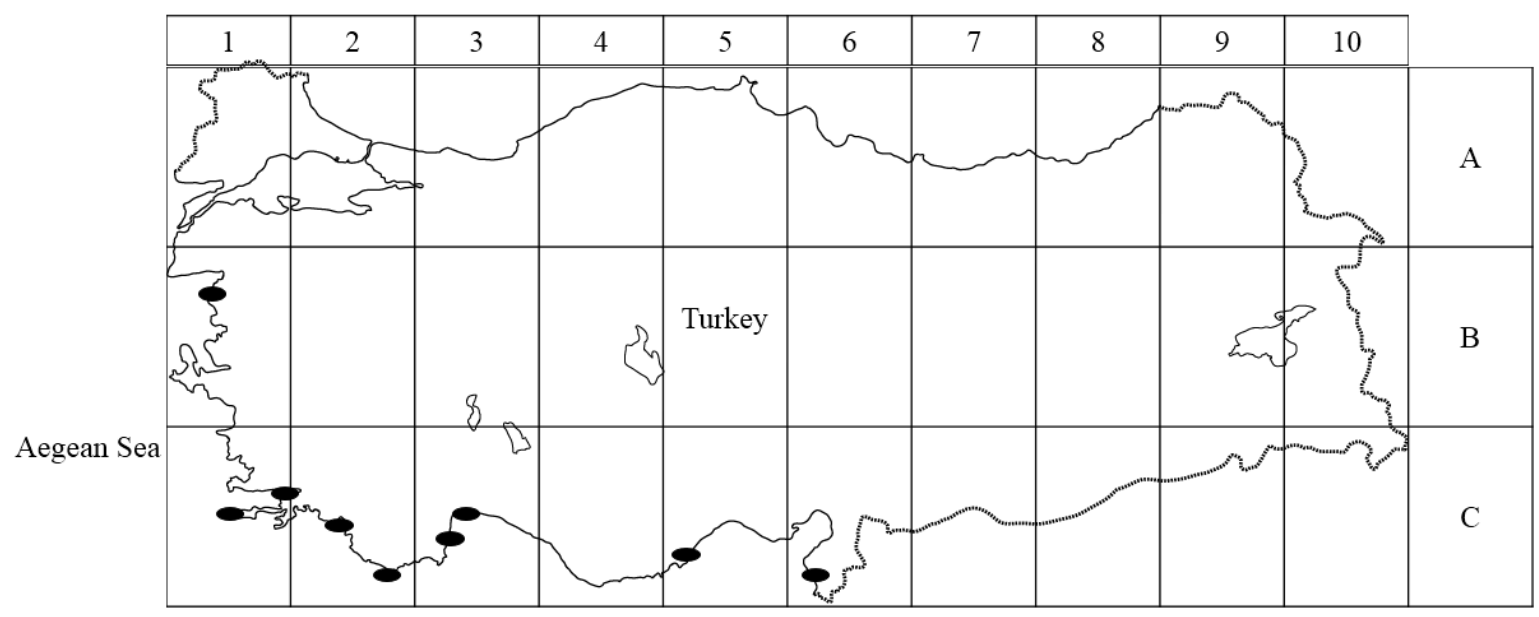

Mediterranean Sea

Figure 1. Geographic locations of collected samples 
Table 1. Distribution of the species among Turkish seas and the location of collected samples (MAP)

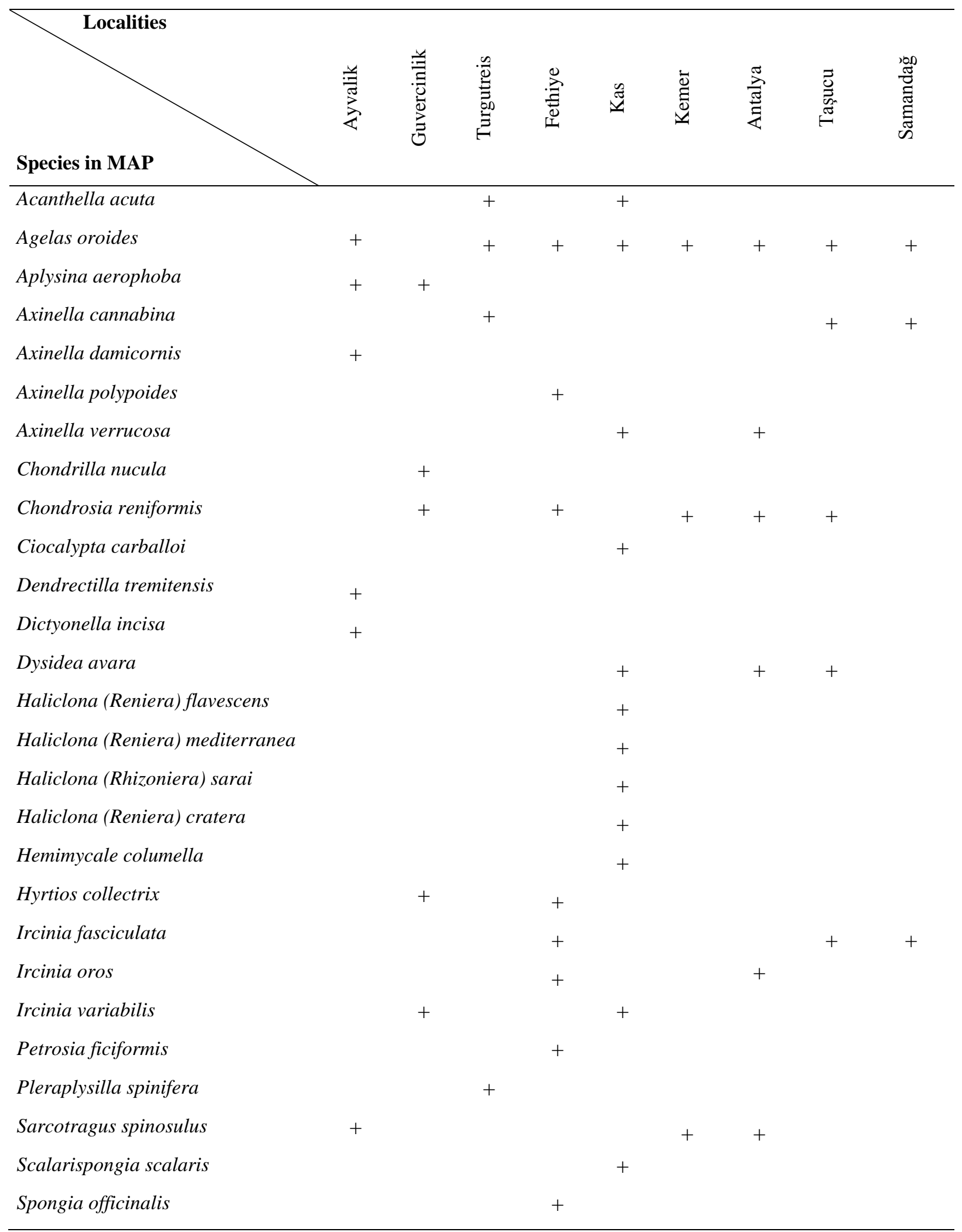

\subsection{Secondary Metabolites Sponges from Turkey}

Secondary metabolites which have been isolated from different species of sponges, collected from the coasts of Turkey, are classified by species. The list of isolated compounds is shown in Table 2. 
Table 2. The secondary metabolites from Turkish sponges

\begin{tabular}{|c|c|c|c|}
\hline Sponges & Compound & Structure & References \\
\hline Dysidea avara & Avarol & & [17] \\
\hline Dysidea avara & Avarone & & {$[17]$} \\
\hline Agelas oroides (Hatay) & Dispacamide $C^{*}$ & & {$[20]$} \\
\hline Agelas oroides (Hatay) & Agelasine D* & & {$[20]$} \\
\hline Agelas oroides (Ayvalık) & $(+)$-Agelasidine $\mathrm{C}^{*}$ & & {$[20]$} \\
\hline Agelas oroides & Oroidin & & {$[22]$} \\
\hline Agelas oroides & $\begin{array}{l}\text { 4,5-Dibromo pyrrol-2- } \\
\text { carboxylic acid }\end{array}$ & & {$[22]$} \\
\hline Agelas oroides & $\begin{array}{l}\text { 25-Hydroxy-24-methyl } \\
\text { cholesterol }\end{array}$ & & {$[22]$} \\
\hline
\end{tabular}


Agelas oroides

Agelas oroides

Agelas oroides

Agelas oroides

Agelas oroides

Agelas oroides

Agelas oroides

Agelas oroides

Spongia officinalis

Spongia officinalis

Spongia officinalis
24-Ethyl-cholest-5a-7-en3- $\beta$-ol

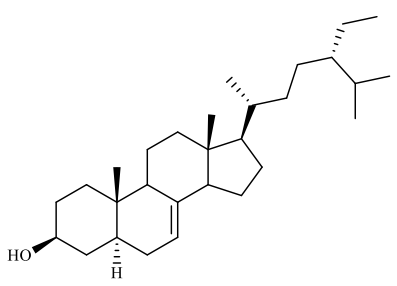

4,5-Dibromopyrrole-2-

carboxylic acid methyl

ester

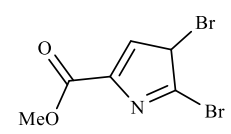

(E)-Oroidin, 3-amino-1-(2aminoimidazoyl)-prop-1ene<smiles>Cc1ncc(/C=C/N)[nH]1</smiles>

Taurine<smiles>[NH3+]CS(=O)(=O)[O-]</smiles>

(5Z,9Z)-5,9-

Tricosadienoic acid

(5Z,9Z)-5,9-

Tetracosadienoic acid

(5Z,9Z)-5,9-

Pentacosadienoic acid<smiles>CC(C)(C)/C=C/CC/C=C/CCCC(=O)CO</smiles>

(5Z,9Z)-5,9-<smiles>CC(C)(C)/C=C/CC/C=C/CCCC(=O)CO</smiles>

Hexacosadienoic acid

4,5-Dibromo-1H-pyrrol-2carbonitrile<smiles>N#Cc1cc(Br)c(Br)[nH]1</smiles>

4,5-Dibromo-1H-pyrrol- 2carboxylic acid ethyl ester

Squalene<smiles>CCOC(=O)c1cc(Br)c(Br)[nH]1</smiles>

Furospinulosin-1<smiles>CC(C)=CCC/C(C)=C/CCC/C(C)=C/CC/C=C(\C)CC/C=C(\C)CCC=C(C)C</smiles>

Furospongin-1<smiles>CC(C)=CCCCC(C)=CCCC(C)=CCCC(C)=CCCC1=CC=CC1</smiles>

II 
Table 2. Continued..

Spongia officinalis

Spongia officinalis

Spongia officinalis

Ircinia spimulosa

Ircinia spimulosa

Ircinia spimulosa

Ircinia spimulosa

Spongia officinalis

Spongia sp.

Ircinia $\mathrm{sp}$
Heptaprenyated $p$-quinol

12 epi-Deoxoscalarin

1,4,44-Trihydroxy-2octaprenylbenzene

4-Hydroxy-3-tetraprenylphenyl acetic acid

Dimethyl-furospongin-4

$11 \beta$-Acetoxyspongi-12-en16-one

4-Hydroxy-3-

octaprenylbenzoic acid

Furospongin

1,4,44-Trihydroxy-2octaprenylbenzene

4-Hydroxy-3-

octaprenylbenzoic acid<smiles>CC(C)=CCc1cc(Cl)ccc1O</smiles> 
Table 2. Continued..

Spongia sp.

Spongia sp.

Spongia sp.

Sarcotragus spinulosus

Sarcotragus spinulosus

Ircinia variabilis

Ircinia fasciculata

Sarcotragus muscarum

Sarcotragus muscarum

Sarcotragus muscarum

Spongia officinalis
Squalene

Furanospinulosin-1

等

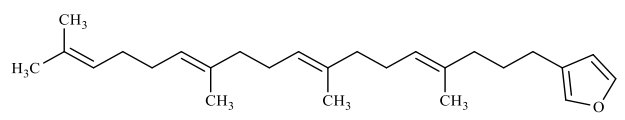

Furospongin-4<smiles>CCOC(=O)/C(C)=C/CC/C(=C/CC/C(C)=C/CC/C(C)=C/CCc1ccsc1)C(C)=O</smiles>

Heptapregnyl

hydroquinone

Octapregnyl hydroquinone

Fasciculatin

Heptaprenylhydroquinone

Ambigol A derivatives

Hexaprenylhydroquinone

Nonaprenylhydroquinone

Ergosterol<smiles>C=C(C)C(C)(C)CC(C)c1cc(Cl)ccc1O</smiles> 
Table 2. Continued.

Spongia officinalis
Axinella cannabina (Hatay) Cylindradine $\mathrm{A}^{*}$
Axinella damicornis
Cictyonella incisa
Chibohlin*

\subsubsection{Dysidea Species}

According to the literature survey avarol and avarone are the major compounds of Dysidea avara. These compounds were also isolated from D. avara, which was collected from İbrice, on the Aegean coast [17].

\subsubsection{Agelas Species}

24-Ethyl-cholest-5a-7-en-3- $\beta$-ol and 4,5-dibromopyrrole-2-carboxylic acid methyl ester were isolated from the hexane fraction of $A$. oroides as major components. 4,5-dibromopyrrole-2-carboxylic acid, (E)-oroidin, 3-amino-1-(2-aminoimidazoyl)-prop-1-ene, taurine, and some minor, complex fatty acid mixtures consisting of a 1:2 mixture of (5Z,9Z)-5,9-tricosadienoic and (5Z,9Z)-5,9tetracosadienoic acids, also another mixture of (5Z,9Z)-5,9-pentacosadienoic and (5Z,9Z)-5,9hexacosadienoic acids were detected in this sponge [18]. 4,5-dibromo-1H-pyrrol-2-carbonitrile, 4,5dibromo-1H-pyrrol- 2-carboxylic acid ethyl ester, 4,5-dibromo-1H-pyrrol-2-carboxylic acid and oroidin were isolated from A. oroides which was collected from Fethiye [19]. Agelasine D, diterpene derivative of hypotaurocyamine, agelasidine $\mathrm{C}$ were isolated from Agelas oroides which was collected from different regions of Hatay and Ayvalik [20]. Bromotyrosine alkaloid, indole alkaloid, pyrrole imidazole alkaloid, bromopyrrole alkaloid and terpenes were detected by DAAD- HPLC from A. oroides which was collected from Kemer [21]. Oroidin, 4,5-dibromopyrrol-2-carboxylic acid, and 25-hydroxy-24methylcholesterol were also isolated from Agelas oroides [22].

\subsubsection{Spongia Species}

Spongia sp. which was collected from Bodrum, was investigated and according to obtained results 1,4,44-trihydroxy-2-octaprenylbenzene, 4-hydroxy-3-octaprenylbenzoic acid, squalene, furanospinulosin-1, furospongin, 2-(hexaprenylmethyl)-2-methylchromenol and 112-epi-deoxoscalarin were isolated [23]. 
Seven known terpenoids, squalene, furospinulosin-1, furospongin-1, 2-(hexaprenylmethyl)-2methylchromenol, heptaprenyated p-quinol, 12 epi-deoxoscalarin, 1,4,44-trihydroxy-2octaprenylbenzene and a mixture of furospongin-3- and 4 were isolated from Spongia officinalis [24]. Ergosterol and furospinulosin-II were isolated from $S$. officinalis. This sponge species was collected from Bodrum,Turkey [25]. Furanoterpenoids (polyprenyl-hydroquinones), furospongins and furospinosulins (polyprenyl-furans) were also isolated from this sponge [26].

\subsubsection{Ircinia Species}

Dimethyl-furospongin-4, 4-hydroxy-3-tetraprenyl phenylacetic acid, 4-hydroxy-3octaprenylbenzoic acid and $7 \beta, 11 \beta$-diacetoxyspongi-12-en-16-one were isolated from Ircinia sp., which was collected from Bodrum,Turkey [23]. Four known terpenoids, 4-hydroxy-3-tetraprenylphenyl acetic acid, dimethyl-furospongin-4 dorisenone D, 11ß- acetoxyspongi-12-en-16-one and 4-hydroxy-3-octaprenylbenzoic acid were isolated from I. spimulosa [24]. Furanoterpenoids (polyprenyl-hydroquinones), furospongins and furospinosulins (polyprenyl-furans) were isolated from three sponges I. spinulosa, I. muscarum which were collected from the Mediterranean Sea [26]. Fasciculatin and heptaprenylhydroquinone were isolated from I. variabilis (Mersin) and I. fasciculata (Fethiye) respectively [19]. Bromopyrrole, indol alkaloids which were also determined by HPLC-DAD were isolated from I. oros and I. variabilis [21].

\subsubsection{Sarcotragus Species}

Heptapregnyl hydroquinone, octapregnyl hydroquinone and prenylated hydroquinone were isolated from S. spinulosus which was collected from Antalya, Turkey [27]. Ambigol A derivatives, hexaprenyl hydroquinone and nonaprenyl hydroquinone were isolated from Sarcotragus muscarum which was collected from Fethiye [19]. Bromopyrrole type alkaloids (Purealidin R, Oroidin, Spongiacidin D, Hymenialdisin, Hymenidin, Stevensin, Aeroplysinin-1), indoline alkaloid (Communesin B), furanosester terpens (Fasciculatin), and terpens (Agelanesin A), were detected by DAAD- HPLC from $S$. spinulosa, sponge species which was collected from Kemer [21].

\subsubsection{Axinella Species}

Cylindradine A and Ugibohlin were isolated from A. cannabina and A. damicornis respectively [20]. Bromopyrrole type alkaloids (Purealidin R, Oroidin, Spongiacidin D, Hymenialdisin, Hymenidin, Stevensin, Aeroplysinin-1), indoline alkaloid (Communesin B), furanosester terpens (Fasciculatin), and terpens (Agelanesin A), were detected by DAAD- HPLC from A.polypoides, sponge species collected from Kemer [21].

\subsection{Bioactivity of Sponge Samples from Turkey}

\subsubsection{Antimicrobial Activities}

The methanol extracts of sponges Agelas oroides (Kemer, Hatay, Ayvalik), Axinella damicornis (Kemer, Hatay, Antalya, Ayvalik), Axinella cannabina (Hatay and Ayvalik), Ircinia spinulosa, Ircinia fasciculata (Kemer and Hatay), Ircinia variabilis, Dysidea avara and Sarcotragus spinulosus (Antalya), which were collected from the Mediterranean sea, were screened for antimicrobial activities against standard and isolated microorganism. Selected sponge extracts showed high activity against Staphylococcus aureus (ATCC 25923) with MIC values between $0.5-1 \mathrm{mg} / \mathrm{mL}$, where ofloxacin and ampicillin had MIC at 0.25 and $0.12 \mathrm{mg} / \mathrm{mL}$, respectively [22].

Antimicrobial activities of methanolic extracts of Spongia officinalis, Spongia agaricina, Aplysina aerophoba (Saros) were tested against Bacillus cereus, Bacillus subtilis, Escherichia coli, Staphylococcus aureus, Staphylococcus epidermidis, Klebsiella pneumoniae, Enterococcus faecalis, Aspergillus niger, Aspergillus fumigatus var. elipticus, Aspergillus flavus, Penicillium granulatum, Penicillium rugulosum, Penicillium jenseii, Aspergillus canditus, Geotrichum candidum and Candida albicans strains. Sponges were collected from three different regions of Saros: six sponges from SarosGallipoli (3-4m), seven sponges from Saros-Gallipoli (10-30m), seven sponges from Saros-Gallipoli 
(10m). Antimicrobial activity of these samples showed that Aplysina aerophoba and Spongia agaricina significantly inhibited both bacterial and fungal growth [28,32].

\subsubsection{Antioxidant Activity}

Antioxidant activities of selected samples were determined by DPPH assay. According to the results Ircinia variabilis (Antalya) exerted the highest scavenging activity rather than the other samples $(65.92 \%$ inhibition at $2000 \mathrm{mg} / \mathrm{mL})$. Ircinia fasciculata -Hatay (68.64\%), Ircinia spinulosa - Kemer (68.19\%), and Dysidea avara (66.90\%) exhibited acetylcholinesterase inhibitory effect at $200 \mathrm{mg} / \mathrm{mL}$ concentration [22].

Antioxidant activities of methanolic extracts of eleven species from six different regions of Turkey were demonstrated by 2,2-diphenyl-1-picrylhydrazil (DPPH), nitric oxide (NO) and superoxide (SO) assays. Theses sponge samples were collected from Kemer, Güvercinlik, Ayvalık , Hatay, Turgutreis and Kaş. According to the results localities of the sponges were found to be effective for the potency of their activities. DPPH radical scavenging activity of methanolic extracts of Dysidea avara $\left(\mathrm{IC}_{50}: 92.8 \mu \mathrm{g} / \mathrm{mL}\right)$ from Kemer, Axinella cannabina $\left(\mathrm{IC}_{50}: 788 \mu \mathrm{g} / \mathrm{mL}\right)$ from Ayval1k, Agelas oroides $\left(\mathrm{IC}_{50}: 553.7 ; 545.1 \mu \mathrm{g} / \mathrm{mL}\right.$ ) from Kemer and Ayvalık, Axinella damicornis $\left(\mathrm{IC}_{50}: 519.5 ; 738.5 \mu \mathrm{g} / \mathrm{mL}\right.$ ) from Kemer and Ayval1k, Axinella verrucosa $\left(\mathrm{IC}_{50}: 432.32 \mu \mathrm{g} / \mathrm{mL}\right)$ from Turgut reis were more active than the other sponge samples. SO radical scavenging activity of methanolic extracts of Dysidea avara $\left(\mathrm{IC}_{50}: 34.1 \mu \mathrm{g} / \mathrm{mL}\right)$ from Kemer, Axinella cannabina $\left(\mathrm{IC}_{50}: 1286.9 \mu \mathrm{g} / \mathrm{mL}\right)$ from Ayvalık, Ircinia fasciculata $\left(\mathrm{IC}_{50}: 1675.9 \mu \mathrm{g} / \mathrm{mL}\right.$ ) and Axinella damicornis $\left(\mathrm{IC}_{50}: 1579.6 \mu \mathrm{g} / \mathrm{mL}\right.$ ) from Kemer and Agelas oroides $\left(\mathrm{IC}_{50}: 1617.2 \mu \mathrm{g} / \mathrm{mL}\right.$ ) from Hatay were most active. NO radical scavenging activity of methanolic extracts of Agelas oroides ( $\mathrm{IC}_{50}: 1977.7 \mu \mathrm{g} / \mathrm{mL}$ ), Dysidea avara $\left(\mathrm{IC}_{50}: 1759.1 \mu \mathrm{g} / \mathrm{mL}\right.$ ), Ircinia spinulosa $\left(\mathrm{IC}_{50}: 1937.9 \mu \mathrm{g} / \mathrm{mL}\right)$, Axinella damicornis $\left(\mathrm{IC}_{50}: 1150 \mu \mathrm{g} / \mathrm{mL}\right)$ from Kemer, Axinella cannabina $\left(\mathrm{IC}_{50}: 1668.9 \mu \mathrm{g} / \mathrm{mL}\right.$ ) from Hatay and Ciocalypta carbolloi $\left(\mathrm{IC}_{50}: 700.7 \mu \mathrm{g} / \mathrm{mL}\right)$ from Kaş showed high antioxidant activity [29].

\subsubsection{Cytotoxic Activity}

The hexane, chloroform and methanol extracts prepared from Axinella sp., were screened for their cytotoxic activity by MTT assay against B16 melanoma cells. The chloroform extract of the sponge showed significant cytotoxic activity [30].

\subsubsection{Other Activities}

The crude extracts and pure compounds and fatty acids mixture which were isolated from Agelas oroides exhibited inhibitory activity against the recombinant PfFabI enzyme. Among the tested components the mixture of fatty acids exerted the highest inhibitory potential $\left(\mathrm{IC}_{50}: 0.35 \mathrm{lg} / \mathrm{mL}\right)$. Fatty acids mixtures also inhibited FabI of Mycobacterium tuberculosis (MtFabI, $\mathrm{IC}_{50} \mathrm{~s} 9.4$ and $8.2 \mathrm{lg} / \mathrm{ml}$, respectively) and Escherichia coli (EcFabI, $\mathrm{IC}_{50} \mathrm{~S} 0.5$ and $0.07 \mathrm{lg} / \mathrm{ml}$, respectively). The secondary metabolite isolated from Agelas oroides exhibited in vitro anti plasmodial, trypanocidal and leishmanicidal activities without cytotoxicity towards mammalian cells [18].

Furanoterpenoids, furospongins and furospinosulins which were isolated from Spongia officinalis, Ircinia spinulosa, Ircinia muscarum sponges showed CDC25 (Cell division cycle 25) phosphatase inhibitor activity. These compounds were screened for their activity against Ser/Thr phosphatase Protein phosphatase 2C (PP2C- $\alpha$ ) and three kinases cyclin-dependent kinase 1 (CDK1 and CDK5), glycogen synthase kinase 3 (GSK-3), but they did not show any activity against these enzymes [26].

Agelasine D which was isolated from Agelas oroides and its butanol fraction significantly inhibited the growth of Trypanosoma brucei to the extent of $98.9 \%$ and $99.2 \%$ respectively at $20 \mu \mathrm{g} / \mathrm{ml}$ of test solutions, which were $1.9 \%$ and $2.2 \%$ more active than that of reference drug (suramin; $\mathrm{p}<0.01$ ). Both agelasine D and A. oroides butanol fraction exhibited $98.3 \%$ and $93 \%$ of prominent growth inhibitory activity against $S$. aureus (p<0.01), but were less active against $E$. coli. Isolation of agelasine $\mathrm{D}$ from Mediterranean sponge Agelas oroides was unprecedented [20].

The crude extract of Axinella damicornis (Ayvalik) was found to have greatest inhibitory effect against trypanosome. Its cytotoxic effect is specific against trypanosome as it inhibits only $8 \%$ of $S$. aureus population and $25.8 \%$ of the population of E.coli. Ethyl acetate extract of A. damicornis (Hatay) 
is also a potent anti-trypanosome agent as its inhibition towards trypanosome is only slightly lesser than the crude extract of A. damicornis (Ayvalik). However, its cytotoxic effect is not as specific as the crude extract of A. damicornis (Ayvalik) as it inhibits $19.5 \%$ of $S$. aureus population and $28.1 \%$ of E.coli population. So, it can be concluded that the crude extract of A. damicornis (Ayvalik) is a more potent anti-trypasnosome agent. Butanol extract of A. cannabina (Hatay) was found to be the least potent antitrypanosome agent as it only inhibits $17.4 \%$ of the population of trypanosome. Besides, its cytotoxic activity against the normal flora (S. aureus and E. coli), was found to be greater than the crude extract of A. damicornis (Ayvalik), which is a most potent agent. This means that the butanol extract has greater inhibitory effect against normal flora compared to trypanosome. So, it can be concluded that the butanol extract of A. cannabina (Hatay) is not suitable to be used as anti-trypanosome agent. All eight samples were found to have greater inhibitory effect towards $E$. coli than against $S$. aureus [20].

In conclusion marine sponges produce a vast array of anticancer, anti-inflammatory, antibiotic, antiviral, immunosuppressive, bioactive compounds that can affect the pathogenesis of many diseases. These different compounds are produced by sponges as means of survival. Sponges with different bioactive compounds can be new and unique sources for drug discovery and industrial uses. Turkey has a long border of sea and a wide diversity of marine species. Despite this, our literature survey demonstrated that there are not enough studies on Turkish marine species, especially on sponges. In this review we have tried to assemble studies about sponge species which were collected from Turkey. Furthermore, there are no studies on Black sea species. The $\mathrm{pH}$, temperature, pressure and salt rate of the Black sea make it a different habitat for sponges and also other marine species. These conditions result in the production of new secondary metabolites with different activities.

Moreover, a new Hymedesmia species, Hymedesmia (Hymedesmia) anatoliensis sp. nov.

was also recorded by our group in west of Turkey, also Axinyssa aurantiaca (Schmidt, 1864), Halichondria (Halichondria) contorta (Sarà, 1961), and Dictyonella incisa (Schmidt, 1880), were added to the fauna of Turkey [16].

\section{Acknowledgment}

These studies presented in this review were partially supported by a TÜBİTAK-Julich Project (SBAG104S109)

\section{ORCID}

Hajar Heydari: 0000-0001-6297-4618

Bülent Gözcelioğlu: 0000-0003-1835-2701

Belma Konuklugil: 0000-0002-4753-0450

\section{References}

[1] M.F. Mehbub, J. Lei, C. Franco and W. Zhang (2014). Marine sponge derived natural products between 2001 and 2010: trends and opportunities for discovery of bioactives, Mar. Drugs. 12, 4539-4577.

[2] M. Laport, O. Santos and G. Muricy (2009). Marine sponges: potential sources of new antimicrobial drugs. Curr. Pharma. Biotechnol. 10, 86-105.

[3] J.W. Blunt, B.R. Copp, W.P. Hu, M.H. Munro, P.T. Northcote and M.R. Prinsep (2003). Marine natural products, Nat. Prod. Rep. 20,1-48.

[4] J.W. Blunt, B.R. Copp, W.P. Hu, M.H. Munro, P.T. Northcote and M.R. Prinsep (2004). Marine natural products, Nat. Prod. Rep. 21, 1-49

[5] J.W. Blunt, B.R. Copp, W.P. Hu, M.H. Munro, P.T. Northcote and M.R. Prinsep (2006). Marine natural products, Nat. Prod. Rep. 23, 26-78.

[6] J.W. Blunt, B.R. Copp, W.P. Hu, M.H. Munro, P.T. Northcote and M.R. Prinsep (2007). Marine natural products, Nat. Prod. Rep. 24, 31-86.

[7] J.W. Blunt, B.R. Copp, W.P. Hu, M.H. Munro, P.T. Northcote and M.R. Prinsep (2008). Marine natural products, Nat. Prod. Rep. 25, 35-94.

[8] J.W. Blunt, B.R. Copp, W.P. Hu, M.H. Munro, P.T. Northcote and M.R. Prinsep (2009). Marine natural products, Nat. Prod. Rep. 26, 170-244.

[9] J.W. Blunt, B.R. Copp, W.P. Hu, M.H. Munro, P.T. Northcote and M.R. Prinsep (2010). Marine natural products, Nat. Prod. Rep. 27,165-237. 
[10] J.W. Blunt, B.R. Copp, W.P. Hu, M.H. Munro, P.T. Northcote and M.R. Prinsep (2011). Marine natural products, Nat. Prod. Rep. 28,196-268.

[11] J.W. Blunt, B.R. Copp, W.P. Hu, M.H. Munro, P.T. Northcote and M.R. Prinsep (2012). Marine natural products, Nat. Prod. Rep. 29, 144-222

[12] S. Perdicaris, T. Vlachogianni, A and Valavanidis (2013). Bioactive natural substances from marine sponges: new developments and prospects for future pharmaceuticals, Nat. Prod. Chem. Res. 1, 10001141000128.

[13] B. Topaloğlu and A. Evcen (2014). Updated checklist of sponges (Porifera) along the coasts of Turkey, Turk. J. Zool. 38,665-676.

[14] A. Evcen, M.E. Çınar, M. Zengin, S. Süer and M. Rüzgar (2016). New records of five sponge species (Porifera) for the Black Sea, Zootaxa 4103, 267-275

[15] B. Topaloğlu, A. Evcen and M.E. Çınar (2016). Sponge fauna in the sea of Marmara, Turk. J. Fish. Aquat. Sci. 16, 51-59.

[16] B. GözcelioğluB. , R.V. Soest, B. Alvarez and Konuklugil (2015). New species of sponges (Porifera, Demospongiae) from the Turkish coast, Turk. J. Zool. 39, 555-559.

[17] N. Aktas, B. Gözcelioğlu, Y. Zang, W. Lin and B. Konuklugil (2010). Avarone and Avarol from the marine sponge Dysidea avara Schmidt from Aegean coast of Turkey, FABAD J. Pharm. Sci. 35, 119-123.

[18] D. Tasdemir, B. Topaloglu, R. Perozzo, R. Brun, R. O’Neill, N.M. Carballeira, X. Zhang, P.J. Tonge, A. Lindeng and P. Rüedi (2007). Marine natural products from the Turkish sponge Agelas oroides that inhibit the enoyl reductases from Plasmodium falciparum, Mycobacterium tuberculosis and Escherichia coli, Bioorg. Med. Chem. 15, 6834-6845.

[19] A. Putz (2009). Secondary metabolites from marine sponges, with focus on the chemical ecology and biochemical characterisation of the stress-induced biotransformation of Aplysina alkaloids Ph.D, Düsseldorf University, Düsseldorf, Germany.

[20] T.M. Ming (2010). Metabolomic profiling of anti-trypanosomal active sponge extracts. Final year research project, University of Strathclyde, England.

[21] N. Aktas, B. Gözcelioğlu and B. Konuklugil (2011). Qualitative detection of some secondary metabolites from Turkish marine sponges collected in Kemer, FABAD J. Pharm. Sci. 36, 129-136.

[22] I.E. Orhan, B. Ozcelik, B. Konuklugil, A. Putz, U.G. Kaban and P. Proksch (2012). Bioactivity screening of the selected Turkish marine sponges and three compounds from Agelas oroides, Rec. Nat. Prod. 6, 356 -367 ,

[23] I. Erdoğan, J. Tanaka, T. Higa and B. Sener (1999). Terpenoids from two sponge species of Aegean sea, Nat. Prod. Sci. 5, 177-180.

[24] I. Erdoğan, J. Tanaka, T. Higa and B. Sener (2000). Two new hydroquinone derivatives from two new sponge species of Aegean sea, J. Chem. Soc. Pak. 22,200-204.

[25] I. Erdoğan and B. Şener (2001) Two metabolite from the marine sponge Spongia officinalis L, Acta Pharma. Sc. 43,17-19.

[26] I. Erdoğan-Orhan, B. Sener, S. de Rosa, J. Perez-Baz, O. Lozach, M. Leost, S. Rakhilin and L. Meijer (2004). Polyprenyl-hydroquinones and -furans from three marine sponges inhibit the cell cycle regulating phosphatase CDC25A, Nat. Prod. Res. 18,1-9.

[27] B. Ergene (2009). Deniz süngerinden sarcotragus spinulosus'un biyoaktif etken maddelerinin izolasyonu ve yap 1 tayini, Master of science, Ankara university, Ankara, Turkey.

[28] H.M. Canakay and B.M. Yapici (2016). Antifungal and antibacterial activities of three marine sponges obtained from the gulf of saros in Turkey, Ann. Bio. Res. 7, 1-6.

[29] N. Aktas, Y. Genc, B. Gözcelioğlu, B. Konuklugil and U.S. Harput (2013). Radical scavenging effect of different marine sponges from mediterranean coasts, Rec. Nat. Prod. 7, 96-104.

[30] F.N. Yalçın (2007). Biological activities of the marine sponge Axinella, Hacettepe Univ. J. Facul. Pharm. 27, 47-60.

[31] H. Heydari, B. Gozcelioglu and B. Konuklugil (2018). In vitro evaluation of bioactivity of Dictyonella incisa from Turkey, Kafkas Univ. Vet. Fak. Derg, 24, 479-482.

[32] P. Ferriol, F.J. T. Marante, I. B. Martin, J.J. S. Rodríguez, R.G. Alonso, A. G. Benkovics and R. Mioso (2018) .Identification and quantification, by NMR and LC-MS, of sterols isolated from the marine sponge Aplysina aerophoba, Rec. Nat. Prod. 12(5), 470-479.

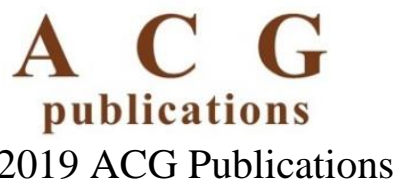

